\title{
Heavy Metals Interaction in Soil-Plant System of Carmagnola cannabis Strain
}

\author{
Dani Fadel ${ }^{1}$, Najoie Assaad ${ }^{2}$, Ali Hachem ${ }^{1}$, Ariadne Argyraki ${ }^{3} \&$ Zacharenia Kypritidou ${ }^{3}$ \\ ${ }^{1}$ Lebanese University, Faculty of Agriculture, Department of Plant Production, Dekwaneh, Lebanon \\ ${ }^{2}$ Department of Languages and Literature, Faculty of Pedagogy, Lebanese University, New Rawda, Lebanon \\ ${ }^{3}$ Faculty of Geology \& Geoenvironment, National \& Kapodistrian University of Athens, Athens, Greece \\ Correspondence: Najoie Assaad, Department of Languages and Literature, Faculty of Pedagogy, Branch 2, \\ Lebanese University, New Rawda, Lebanon. Tel: 961-168-0193. E-mail: najoie.assaad@outlook.com
}

Received: April 17, 2020

doi:10.5539/jas.v12n7p163
Accepted: May 31, $2020 \quad$ Online Published: June 15, 2020

URL: https://doi.org/10.5539/jas.v12n7p163

\begin{abstract}
Evolution in the legislation of Cannabis in Lebanon regarding production and consumption of related products for medicinal and recreational uses is leading to emerging regulations regarding the potency and cannabinoid profiles. On 21 April 2020, the Parliament passed a law legalizing cannabis cultivation for medical use. The objective of this work was to estimate the heavy metals accumulation in the soil-plant system and to help the governmental regulatory body on having also into account the impurities of metals within their rules of regulation. The impurity content of hyperaccumulating metals (zinc, chromium, arsenic, manganese, cadmium, barium, aluminum, iron, cobalt, nickel, copper and lead) was evaluated by inductively coupled plasma atomic emission spectrometry (ICP-OES) taking into account the pseudototal and mobilizable concentrations of the elements in the rhizosphere of plants and the total concentrations of their aerial parts and spikes from allotments in Kropia region-Athens, Greece. The main physicochemical assets of topsoil samples such as $\mathrm{pH}(7.99 \pm 0.05)$ and organic matter content (rich), the X-ray crystallography test (basically quartz, albite and vermiculite) and soil texture determination test (basically sandy loam soil) were also determined. The concentrations of most of our studied elements in soil plant system samples were recorded below or around the plant reference material concentrations used in our analysis. Results showed also that $\mathrm{Al}$ was highly toxic in soil and plant samples. In the plant samples, the arsenic was nearly absent and the lead, nickel, copper, chromium and cadmium contents were less than those found in the plant reference material. In the soil samples, only copper and zinc concentrations were found to be within the accepted ranges. The maximum transfer factor is found in lead ( $\mathrm{Tf}-\mathrm{Pb}=0.8223$ ). Average transfer factor of elemental concentrations showed that heavy metals were not easily translocated in the soil-plant system $(0.0514 \pm 0.0032)$. In addition, hemp plants that are considered as "hyper-accumulators" showed very acceptable results for industrial and other uses.
\end{abstract}

Keywords: hyperaccumulating metals, hemp, digestion, transfer factor

\section{Introduction}

Since April 2020, the Lebanese parliament approved the legislation of Cannabis cultivation (Cannabis sativa L.) for medicinal and industrial purposes. Lebanon became the first Arab country to legalize cannabis farming in the hopes that sales from the plant will provide some relief to its debt-ridden economy. Consultants hired by Lebanon from the New York-based global consulting company McKinsey had estimated the cultivation of cannabis in Lebanon could generate up to $\$ 1$ billion per year in government revenue. Lebanese cannabis cultivation body will be soon officially nominated for the regulation of cannabis planting, harvesting and manufacturing. After Morocco and Afghanistan, Lebanon is the third-largest source of cannabis resin worldwide, according to the United Nations.

The Concern in soil-plant relationships about heavy metal loading from soils to plants is increased over the past few decades and awareness of metal contamination in human food sources is amplified. Cannabis plants fix metals from their environment within proteins and fluid within the plants. Heavy metals are one of several possible contaminants in cannabis and cannabis products, in addition to pesticides, microbial organisms, and residual solvents (Kapustka et al., 2004; Sarma, 2011). The Food and Drug Administration (FDA) recommends 
that the four heavy metal elements cadmium $(\mathrm{Cd})$, arsenic $(\mathrm{As})$, lead $(\mathrm{Pb})$ and mercury $(\mathrm{Hg})$ should be evaluated during "the risk assessment, across all potential sources of elemental impurities and routes of administration" for all drug products, drug substances, and excipients because they fall into the US Federal FDA Class 1 category, which lists substances that are "human toxicants that have limited or no use in the manufacture of pharmaceuticals." The heavy metals are known to be highly toxic especially because the body is unable to remove these metals efficiently after exposure (by respiration or other uses) Direct studies on the health effects of such contaminants from cannabis, are currently lacking. As cannabis becomes a more prominent commodity, testing requirements can vary from a city to city in the whole world (Aubin, 2014).

Bioavailability of heavy metals in soils is critically dependent on the chemical speciation of the metals and plants respond only to the fraction that is "phytoavailable" (Chang et al., 2014). The readily soluble fraction of heavy metals in soil is generally considered to be phytoavailable, but there is growing awareness that the various methods for assessment of "soluble" and "phytoavailable" fraction need reevaluation. It is generally known that there are variations in the rates of soil to plants transfer between different plant species but also between the same plant species from different areas (McLaughlin et al., 2011).

In this study and for the first time, Carmagnola strain of Cannabis was selected in order to assess the contamination levels of heavy elements in its soil - plant system (zinc, chromium, arsenic, manganese, cadmium, barium, aluminum, iron, cobalt, nickel, copper and lead) in order to confirm the promising quality of the end product after harvesting. For this reason, the concentrations of pseudototal heavy metals elements in soils, the concentration of the phytoavailable heavy metal and the concentration of heavy metals in the inflorescence of Carmagnola studied plants were also assessed. The study of the physicochemical properties, mineralogy crystals and texture of the soil samples was analyzed in order to understand the low possibilities of heavy metals translocation in the soil plant system. The transfer factors of heavy metals elements with their averages and standard deviation at 0.05 significance level were also calculated.

\section{Material and Methods}

\subsection{Field Sampling and Treatment}

Soil and plant samples were collected in the summer of 2019 from the area of Kropia in Athens-Greece, located $16 \mathrm{~km}$ southeast of Athens at the fringes of the metropolitan area with geographical coordinates of $37^{\circ} 48^{\prime} 35.6^{\prime \prime} \mathrm{N}$, $23^{\circ} 51^{\prime} 35.2^{\prime \prime}$. Each plant sample was accompanied by its rhizosphere soil sample (depth 0-10 cm). The three soil samples were collected and were replicated three times. Note that we chose the Athens' soils and plants due to the law restriction present on cannabis cultivation in the Lebanese territories. The selected plant samples were eight and were composed of shoots, leaves and two spikes. All samples were collected into plastic bags, dried at a $50{ }^{\circ} \mathrm{C}$ temperature for 48 hours and sieved at $2 \mathrm{~mm}$ diameter in the Faculty of Geology and Geoenvironment, in the National and Kapodistrian University of Athens and were kept for additional selection and analysis (Figure 1). The parts of plants were selected, thoroughly washed three times with deionized water before being dried. All dried samples were finely ground using automated agate mill. 


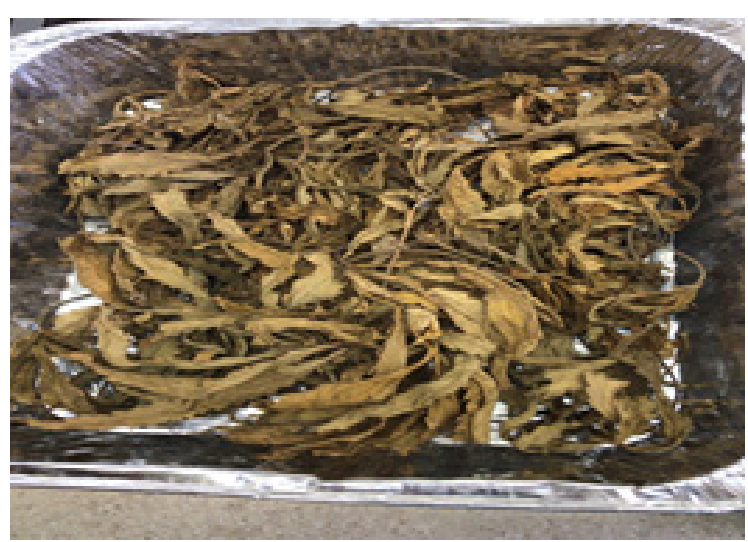

A

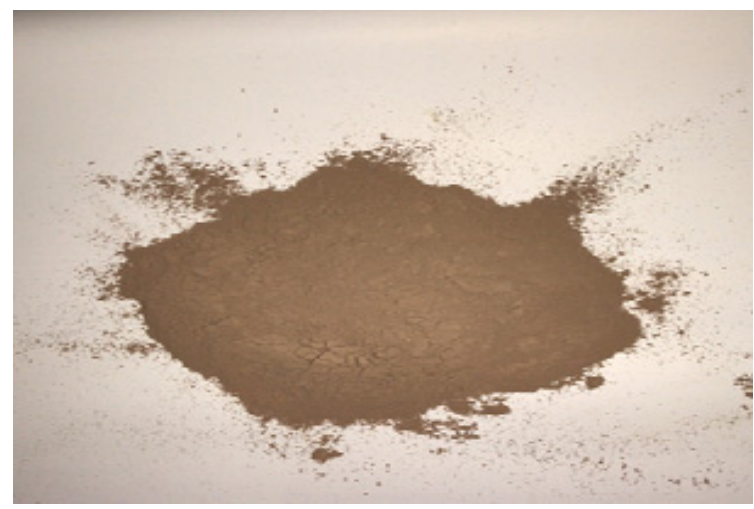

$\mathrm{C}$

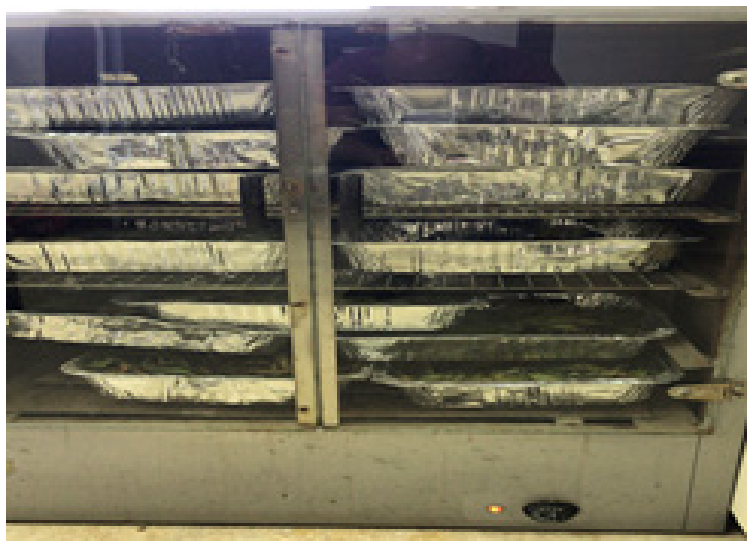

B

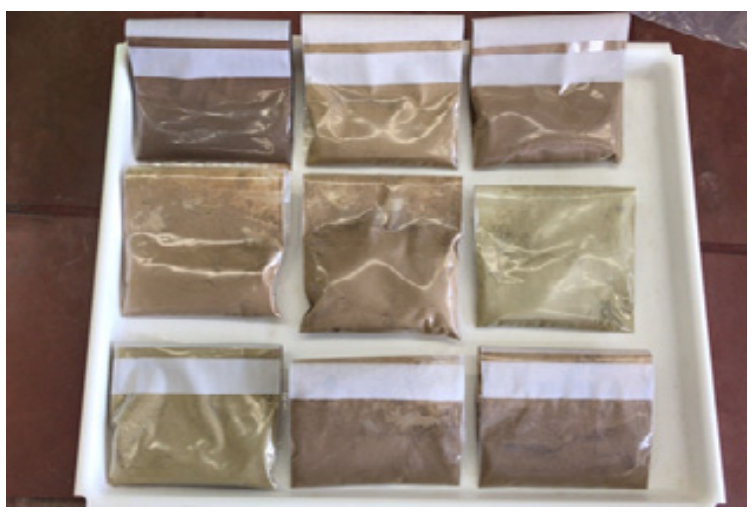

$\mathrm{D}$

Figure 1. Dried (A and B), sieved (C) and stored (D) plant samples

\subsection{Chemical Analysis of Soil and Plant Samples}

The main physicochemical assets of topsoil samples were assessed $(\mathrm{pH}$, Organic matter and X-ray crystallography). The $\mathrm{pH}$ was measured in a soil deionized water suspension (soil:water, 1:2.5 by volume) by a calibrated $\mathrm{pH}$ meter. The total organic matter content method (TOC $\times 1.72)$ was determined by heating $1 \mathrm{~g}$ of each sample to $4500{ }^{\circ} \mathrm{C}$ for 4 hours in a furnace oven and the mineralogical evaluation was conducted using the software (Difrac plus v2.2) by Siemens and the analysis was performed using the program (Eva). The grain size distribution in the sand, silt and clay fractions was also determined using the Bouyoucos Hydrometer Method (Bouyoucos, 1962). The total elemental concentrations of plants were measured by Inductively Coupled Plasma Optical Emission Spectroscopy (ICP-OES) in the University of Portsmouth, UK following microwave digestion by $\mathrm{HNO}_{3} / \mathrm{H}_{2} \mathrm{O}_{2}, 6: 1 \mathrm{v} / \mathrm{v}$. The pseudo-total elemental concentrations of soil samples were measured by aqua regia digestion $\left(\mathrm{HNO}_{3}-\mathrm{H}_{2} \mathrm{O}_{2}-\mathrm{HCl}\right.$ ) (US-EPA, 2002). The mobile elemental content of the soils was determined by weak extraction using acetic acid $(0.43 \mathrm{M})$ after mixing $1 \mathrm{~g}$ of the soil samples (less than $2 \mu \mathrm{m}$ diameter) with 40 $\mathrm{ml}$ of $0.43 \mathrm{M} \mathrm{HAc}$ and shaking for $16 \mathrm{~h}$ at room temperature in an overhead shaker (Groenenberg et al., 2017).

\subsection{Data Analysis and Quality Control}

The descriptive statistics of the physicochemical properties of soil samples (mean, median, standard deviation, minimum and maximum) and average of concentrations heavy metals accumulation were determined. The extractability percentages of each element were estimated and were presented in terms of the ISO 9001: 2015 in accordance with the requirements of the quality assurance system. Water Certified Reference Material or Water (CRM), Plant CRM (Recovery percentage range $\sim 100 \%$ ), Aqua Regia Soil Digestion (Recovery percentage range $\sim 100 \%$ ) were assessed with a significance level $<0.05$. Transfer factors and transfer factor averages from soils to vegetables \pm standard deviation were calculated and presented in the form of histograms with bars in order to assess the mobility of the average heavy metal into the plant and the spikes. Transfer factor was calculated using the following equation (Chojnacka et al., 2005): 


$$
T F=\frac{\text { Cplant }}{\text { Ctotal }- \text { soil }}
$$

Where, $C_{\text {plant }}$ is the concentration of an element in the plant material (dry weight basis) $C_{\text {total-soil }}$ is the total concentration of the same element in the soil (dry weight basis) where the plant is grown. The higher the value of the TF, the more mobile/available the metal is.

The analytical quality control procedures included the performance of triplicate analysis, the inclusion of blank solutions and certified reference materials of soils (NIST SRM 2709 and NIST SRM2711a for the total analysis and BCR-483 and BCR-484 for the acetic acid extraction) at random positions within the analytical batches. The obtained results from analytical control were found within acceptable limits for all geochemical results.

\section{Results and Discussion}

\subsection{Physicochemical Properties of Soil Samples}

The statistical summary of physicochemical properties including $\mathrm{pH}$, organic matter and texture (sand, silt, clay\%) of investigated soil samples are shown in table 1 . The $\mathrm{pH}$ values of soil samples ranged from 7.87 to 8.1 (Moderately alkaline). The $\mathrm{pH}$ mean is about 7.98 and the $\mathrm{pH}$ median is also about 7.98 with a standard deviation of 0.07 . The OM average percentage value of $4.95 \%$ was considered very high for urban agriculture soils and this may be due to the crystal types of minerals (vermiculite, anorthite, albite and dolomite) composing the soil material and reacting with the ions of studied heavy metals.

Most of soil textures were sandy loam (means of sand and clay were 59.15 and $18.48 \%$, respectively). The minimum and the maximum sand percentage was 57.12 and 61.21 giving a sandy clay loam to sandy loam texture and confirming the homogeneity of the soils cultivated with Carmagnola plant.

Table 1. Summary of physiochemical characteristics (pH and organic matter) and texture of the examined soil samples) in communal studied allotments

\begin{tabular}{|c|c|c|c|c|c|c|}
\hline Soil Sample & pH & O.M.\% & Sand (\%) & Clay (\%) & Silt (\%) & Texture \\
\hline Sample $1_{A}$ & 7.87 & 6.72 & 61.21 & 16.48 & 22.4 & Sandy loam \\
\hline Sample $1_{B}$ & 7.96 & 7.57 & 61.21 & 16.48 & 22.4 & Sandy loam \\
\hline Sample $2_{A}$ & 8.00 & 4.36 & 59.12 & 18.48 & 22.4 & Sandy loam \\
\hline Sample $2_{B}$ & 8.1 & 5.35 & 59.12 & 18.48 & 22.4 & Sandy loam \\
\hline Sample $3_{A}$ & 7.97 & 2.61 & 57.12 & 20.48 & 22.4 & Sandy clay loam \\
\hline Sample $3_{B}$ & 8.02 & 3.14 & 57.12 & 20.48 & 22.4 & Sandy clay loam \\
\hline
\end{tabular}

Soil mineral characterization or X-ray crystallography of hemp rhizosphere samples were presented in diffractograms (Figures 2, 3, and 4). Figure 2 showed that Albite, Calcite, Anorthite, Quartz, Vermiculite, Kaolinte and Talc was found. The "Dolomite" newly appeared in the second soil rhizosphere sample (SS2) in addition to Albite, Quartz, Anorthite, Calcite, Dolomite, Vermiculite and Kaolinite (Figure 3). The third soil sample (SS3) presented that the minerals found are quartz, calcite, albite, vermiculite and kaolinite (Figure 4). 


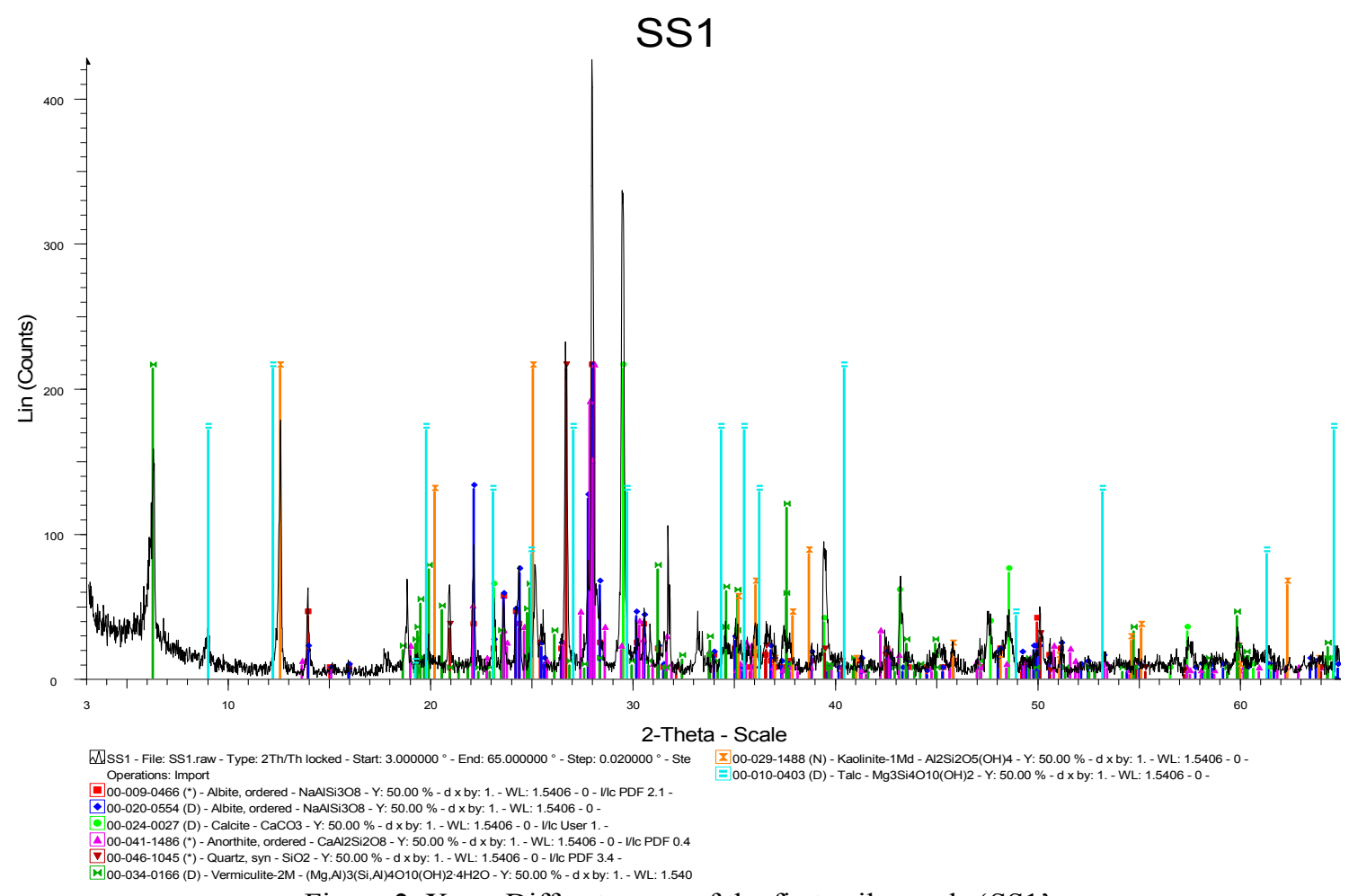

Figure 2. X-ray Diffractogram of the first soil sample 'SS1'

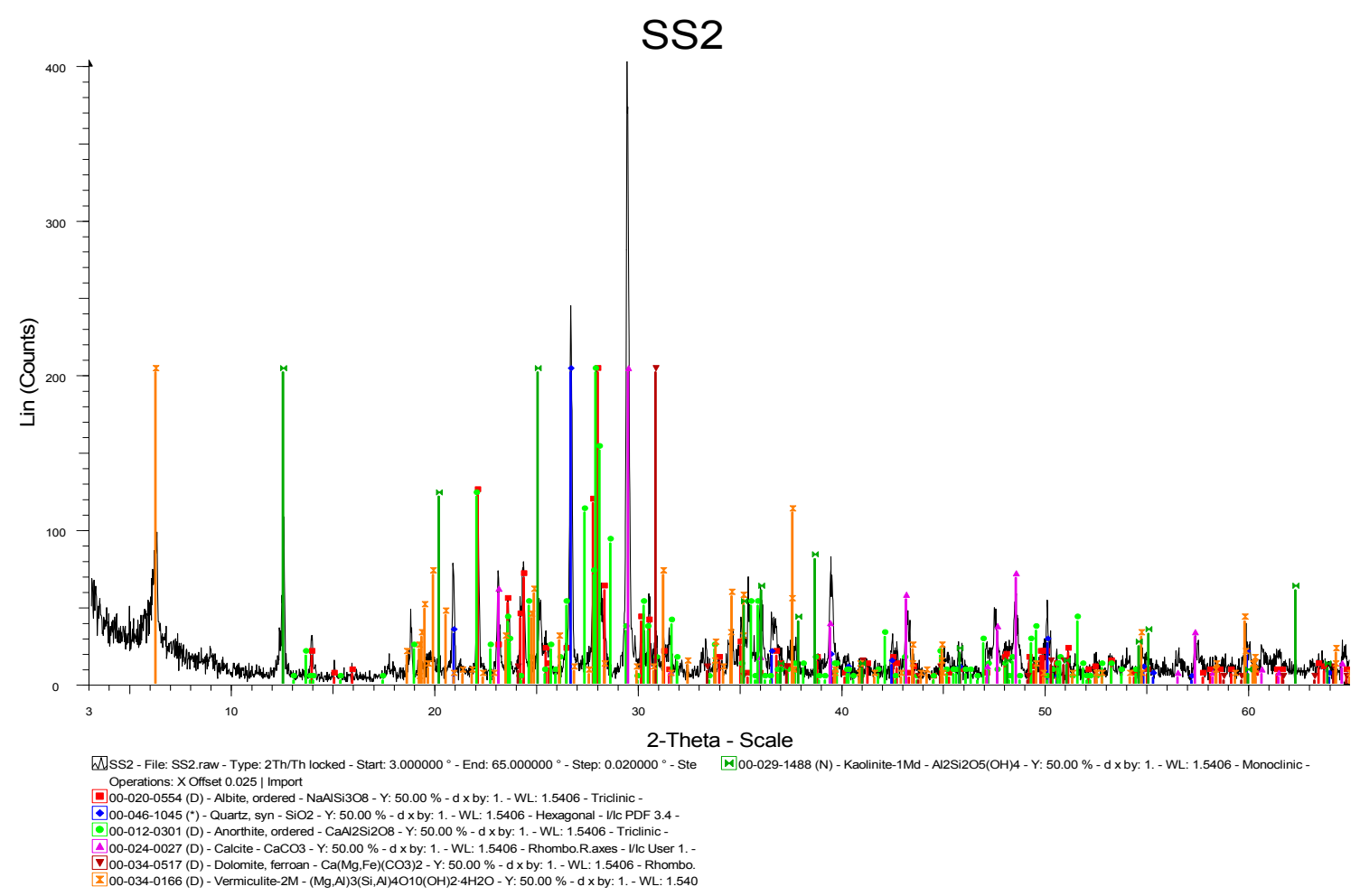

Figure 3. X-ray Diffractogram of the second soil sample 'SS2' 


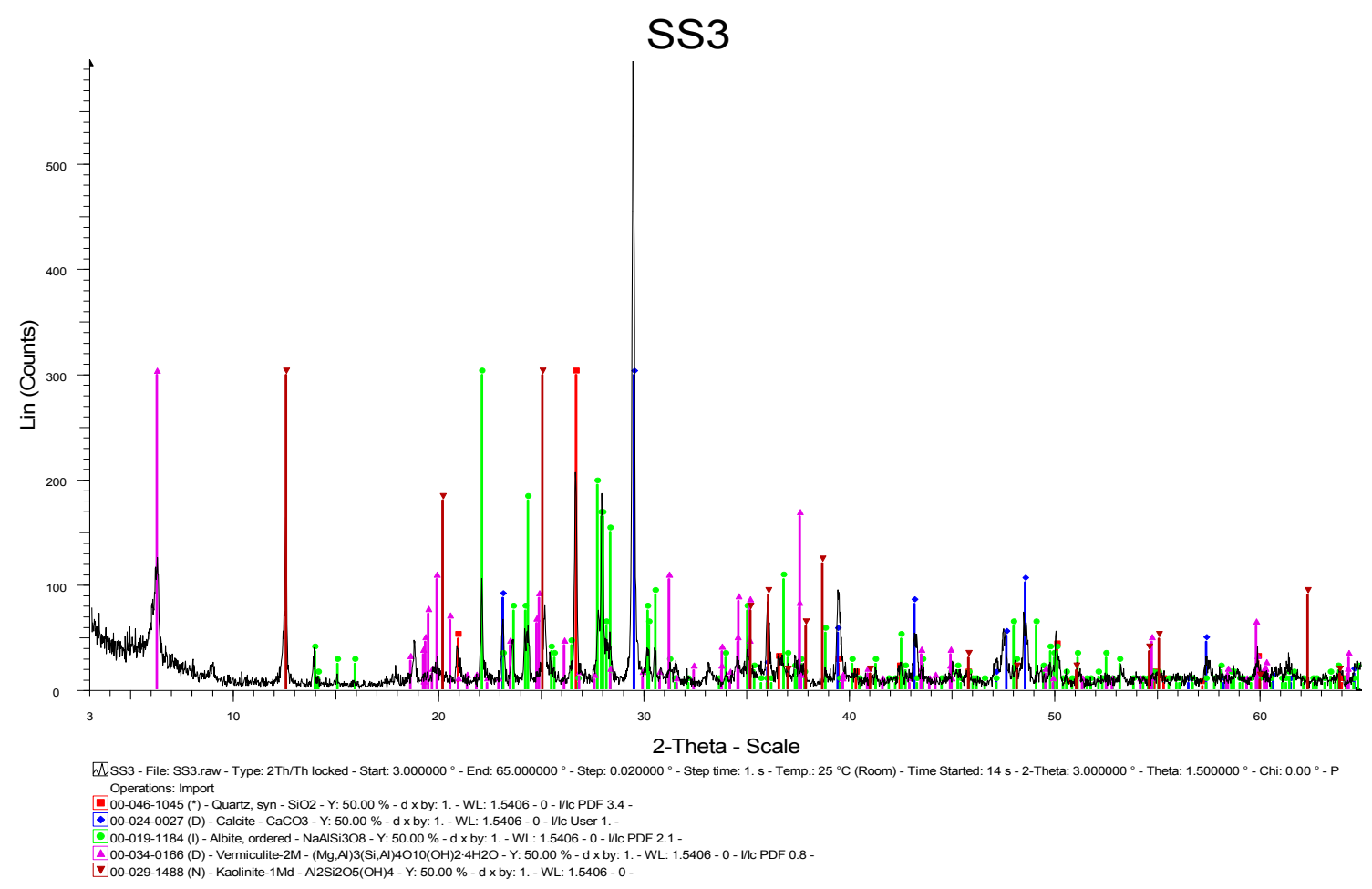

Figure 4. X-ray Diffractogram of the third soil sample 'SS3'

These formed phases that were identified and shown by the X-ray diffractograms in the figures 1,2 and 3, showed that the main detected phases were those of "Quartz", "Calcite", "Vermiculite", "Albite" and "Kaolinite". Quartz is the main mineral found in our soils samples. It is very resistant to weathering and a primary mineral inherited in soils tending to grow by weathering and dissolution of additional minerals (Nash et al., 2014). Other observed segments showed "Kaolinite clays". Our kaolinite is rich in aluminum and typically formed by the weathering of feldspars and felsic rocks. Kaolinite has no important cations exchange capacity; whereof valuable cations that could be concerned for plant uptake (Ogasawara et al., 2013). Litter phases showed "Calcite and dolomite". Dolomite and calcite, known as carbonates minerals, could be shaped from limestones and were effortlessly weathered and assembled as primary minerals. Carbonate minerals and vermiculite were listed as the principal paragenesis for mineral groups in soils as primary minerals and were publicized to persist in the weathered parental materials, while kaolinite is designed to form secondarily from weathering of the main minerals (Schwertmann, 1999). In our study, the X-ray crystallography reflected different parent materials but recommended that much of the soil minerals suite is reliant on weathering most probably; a soil forming process that can impact soil mineralogy at all scales. Our kaolinite, vermiculite and albite containing aluminum were typically formed by the weathering of feldspars and felsic rocks. Kaolinite has no important cations exchange capacity while vermiculite and albite showed to have for the valuable cations that could be of concern for plant uptake as shown also by Ogasawara et al (2013). For this reason, heavy metals interaction in soil-plant system of Carmagnola cannabis strain did not show any 'hyper-accumulation' in the studied spikes of interest.

\subsection{Heavy Metal Concentrations in Soil- Plant System and Transfer Factors}

Heavy metals availability from soils to plants is strongly related to the concentration and specification of these elements in the soil solution whereof the plants uptake. The total and available heavy metals concentrations in soil samples were measured using aqua regia and weak acetic acid extractions using ICP-OES. The mean heavy metal element content (mg/Kg DW) of the soil and plant samples (SS1, SS2, SS3 and PS1, PS2, PS3) in addition to the Plant Reference Material (PRMT) and plant inflorescence from Kropia region was determined (Table 2). Mean values of the total and available elements concentrations in soil are by the following decreasing order $\mathrm{Fe}>$ $\mathrm{Al}>\mathrm{Mn}>\mathrm{Ba}>\mathrm{Zn}>\mathrm{Cr}>\mathrm{Ni}>\mathrm{Co}>\mathrm{Cu}>\mathrm{Pb}>\mathrm{As}>\mathrm{Cd}$ and $\mathrm{Fe}>\mathrm{Al}>\mathrm{Mn}>\mathrm{Ba}>\mathrm{Zn}>\mathrm{Cr}>\mathrm{Ni}>\mathrm{Co}>\mathrm{Cu}>$ $\mathrm{As}>\mathrm{Pb}>\mathrm{Cd}$ respectively at a significant level less than 0.05 . 
Table 2. Heavy metal element content in $\mathrm{mg} / \mathrm{Kg}$ DW of soil (SS1, SS2, SS3) and plant samples (RRMT, PS1, PS2, PS3, PI) from Kropia region

\begin{tabular}{|c|c|c|c|c|c|c|c|c|}
\hline \multirow{2}{*}{ Heavy metal } & \multicolumn{3}{|c|}{ Soil Samples concentrations (mg/Kg DW) } & \multicolumn{5}{|c|}{ Plant Samples concentrations (mg/Kg DW) } \\
\hline & SS1 & SS2 & SS3 & PRMT & PS1 & PS2 & PS3 & PI \\
\hline Al & 94500.28 & 39282.28 & 111174.51 & 727.22 & 666.65 & 642.44 & 653.88 & 300.71 \\
\hline As & 24.78 & 16.43 & 24.28 & 3.99 & $\#^{*}$ & 0.00 & 0.00 & $\#^{*}$ \\
\hline $\mathbf{B a}$ & 217.37 & 104.59 & 371.73 & 11.54 & 8.61 & 8.97 & 8.85 & 8.79 \\
\hline Cd & 3.13 & 1.50 & 5.49 & 0.36 & 0.02 & 0.02 & 0.03 & 0.23 \\
\hline Co & 37.88 & 127.93 & 197.44 & 5.11 & 4.44 & 4.74 & 4.30 & 5.04 \\
\hline $\mathrm{Cr}$ & 214.43 & 104.56 & 276.04 & 1.39 & 2.04 & 2.87 & 2.62 & 0.51 \\
\hline $\mathbf{C u}$ & 44.90 & 55.09 & 87.75 & 15.65 & 1.00 & 0.87 & 0.80 & $\#^{*}$ \\
\hline $\mathbf{F e}$ & 108834.27 & 70211.74 & 227124.40 & 806.15 & 863.80 & 827.93 & 857.48 & 406.73 \\
\hline Mn & 1937.87 & 820.90 & 3159.51 & 45.48 & 108.81 & 98.90 & 101.87 & 64.41 \\
\hline $\mathbf{N i}$ & 113.72 & 103.11 & 245.79 & 2.11 & 0.73 & 0.57 & 0.68 & $\#^{*}$ \\
\hline $\mathbf{P b}$ & 13.91 & 42.32 & $\#^{*}$ & 14.19 & 11.44 & 10.28 & 9.66 & 7.92 \\
\hline Zn & 248.33 & 182.40 & $\#^{*}$ & 60.35 & 19.37 & 18.46 & 18.82 & 17.13 \\
\hline
\end{tabular}

Note. $\#^{*}$ Concentration below the detection limit $(0.1 \mathrm{mg} / \mathrm{kg} \mathrm{DW})$.

The total and available elements that can be transferred from soils to Carmagnola strain plants and spikes (Table 2) that the soil allotments were extremely contaminated with different heavy. Lower concentrations were shown in the phytoavailable concentrations that were most probably captured by clay-humus soil or organo-metallic complexes.

The transfer factors (TFs) of heavy metals from soil to plants were presented (Table 3). Also, the average transfer factor \pm standard deviation was calculated and presented (Figures $5 \mathrm{~A}, 5 \mathrm{~B}$, and $5 \mathrm{C}$ ) in order to assess the mobility of the average heavy metal into the plant and the spikes (Figure 5D).

Table 3. Transfer factors (TFs) of heavy metals from soil to plants

\begin{tabular}{|c|c|c|c|c|c|c|c|c|c|c|c|c|}
\hline \multirow{2}{*}{$\begin{array}{l}\text { Plant S. } \\
\text { Soil S. }\end{array}$} & \multicolumn{3}{|c|}{ Plant sample 1} & \multicolumn{3}{|c|}{ Plant sample 2} & \multicolumn{3}{|c|}{ Plant sample 3} & \multicolumn{3}{|c|}{ Plant inflorescence } \\
\hline & SS1 & SS2 & SS3 & SS1 & SS2 & SS3 & SS1 & SS2 & SS3 & SS1 & SS2 & SS3 \\
\hline \multicolumn{13}{|l|}{ Element } \\
\hline Al & 0.007 & 0.017 & 0.006 & 0.006 & 0.016 & 0.0058 & 0.006 & 0.016 & 0.005 & 0.0032 & 0.0077 & 0.0027 \\
\hline As & 0 & 0 & 0 & 0 & 0 & 0 & 0 & 0 & 0 & 0 & 0 & 0 \\
\hline $\mathbf{B a}$ & 0.039 & 0.082 & 0.023 & 0.041 & 0.085 & 0.0241 & 0.040 & 0.084 & 0.023 & 0.0404 & 0.084 & 0.0236 \\
\hline Cd & 0.007 & 0.015 & 0.004 & 0.007 & 0.015 & 0.0042 & 0.009 & 0.019 & 0.005 & 0.0743 & 0.1554 & 0.0424 \\
\hline Co & 0.117 & 0.034 & 0.022 & 0.125 & 0.037 & 0.024 & 0.113 & 0.033 & 0.021 & 0.1331 & 0.0394 & 0.0255 \\
\hline $\mathrm{Cr}$ & 0.009 & 0.019 & 0.007 & 0.013 & 0.027 & 0.0104 & 0.012 & 0.025 & 0.009 & 0.0024 & 0.0048 & 0.0018 \\
\hline $\mathrm{Cu}$ & 0.022 & 0.018 & 0.011 & 0.019 & 0.015 & 0.0099 & 0.017 & 0.014 & 0.009 & 0 & 0 & 0 \\
\hline $\mathrm{Fe}$ & 0.0079 & 0.0123 & 0.0038 & 0.0076 & 0.0118 & 0.0036 & 0.0079 & 0.0122 & 0.0038 & 0.0037 & 0.0058 & 0.0018 \\
\hline Mn & 0.0561 & 0.1326 & 0.0344 & 0.051 & 0.1205 & 0.0313 & 0.0526 & 0.1241 & 0.0322 & 0.0332 & 0.0785 & 0.0204 \\
\hline $\mathbf{N i}$ & 0.0064 & 0.0071 & 0.003 & 0.005 & 0.0056 & 0.0023 & 0.0059 & 0.0065 & 0.0027 & 0 & 0 & 0 \\
\hline $\mathbf{P b}$ & 0.8223 & 0.2703 & 0 & 0.7389 & 0.2429 & 0.00223 & 0.6943 & 0.2282 & 0 & 0.5696 & 0.1872 & 0 \\
\hline Zn & 0.078 & 0.1062 & 0 & 0.0743 & 0.1012 & 0 & 0.0758 & 0.1032 & 0 & 0.069 & 0.0939 & 0 \\
\hline Average & 0.0976 & 0.0595 & 0.0095 & 0.0907 & 0.0564 & 0.0098 & 0.0861 & 0.0554 & 0.0092 & 0.0774 & 0.0547 & 0.0099 \\
\hline St. Dev. & 0.2212 & 0.0757 & 0.0106 & 0.1986 & 0.0682 & 0.0102 & 0.1863 & 0.0652 & 0.0101 & 0.1537 & 0.0626 & 0.0138 \\
\hline
\end{tabular}

If the ratios $>1$, the plants have accumulated elements, the ratios around 1 indicate that the plants are not influenced by the elements and ratios $<1$ show that plants exclude the elements from the uptake (Olowoyo et al, 2010). TF value of $\mathrm{Pb}$ in plants is the highest in all our samples varying from (0.82230 to 0.1872) both are less than "1" so it makes our produce eligible and consumable.

Normally a higher TF indicates a higher transfer capacity of heavy metal elements from the soil to the plant. According to results of the present study, we planted our Carmagnola crops in a soil infected with heavy metals, but due to the high amounts of organic matter content forming clay-humus soil complex and organo metallic complexes, the heavy metals are blocked in the soil and can be transferred with a very little amount to the spike 
of the plant $(0.005 \pm 0.0003)$. Metals accumulation fluctuates and depends on numerous factors such as, soil properties (e.g., organic matter, metal concentration soil $\mathrm{pH}$ and clay content), plant factors (e.g., plant type and panting mode) and other environmental conditions (e.g., industrial pollution and atmosphere) (Thomas et al., 2016). Therefore, caution must be taken into consideration when making definite agricultural planting plans especially for hyperaccumulating plants of heavy metals like Cannabis (McPartland \& McKernan, 2017). The total elements in the plants and soils with respect to the norms deviation of this study were presented in the following charts using Microsoft Excel 2010.
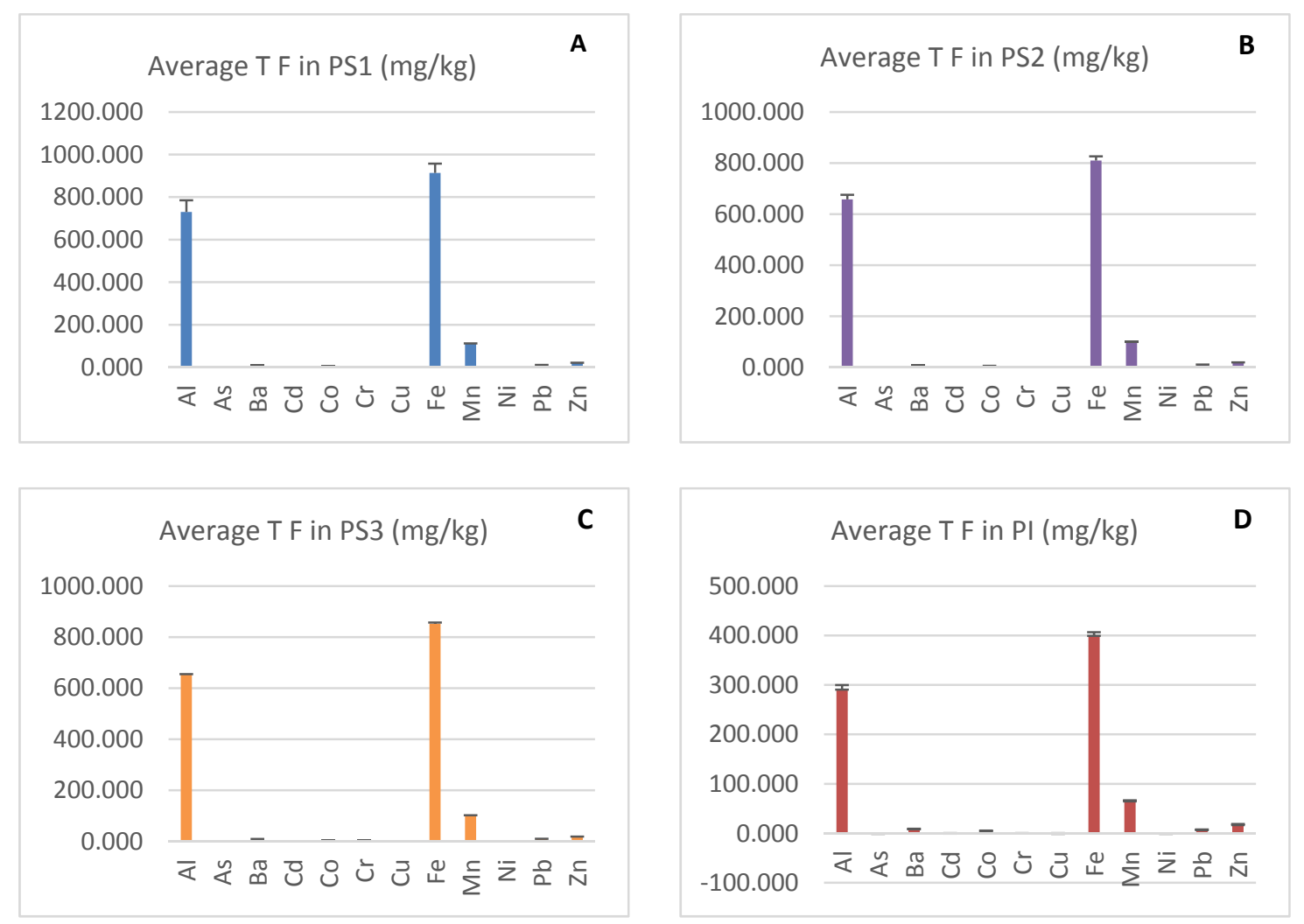

Figure 5. Average transfer factor \pm standard deviation calculated and presented in the form of histograms with bars in plant samples (A: 1, B: 2, C: 3) and inflorescence (D: 4)

\section{Conclusions}

Carmagnola cultivation can be used for bioremediation in poor soils with Nitrogen and organic matter. The concentration of heavy metals in the spikes of the cultivated Carmagnola in Kropia area of Athens in Greece didn't exceed the concentrations found in the plant reference material due to the presence of Kaolinite, vermiculite and albite containing aluminum in addition to high concentration of organic matter content in the soil samples.

Kaolinite, vermiculite and albite were typically formed by the weathering of feldspars and felsic rocks. Kaolinite has no important cations exchange capacity while vermiculite and albite showed to have for the valuable cations that could be of concern.

The study of heavy metals in environmental components of planned areas is recommended and must be frequent. Sources of pollutants should be also studied in order to be reduced or prevented. The recovery of plant and soils contamination is essential not only to preserve plant and soil but also in order to protect the ecosystem and protect the humans from the hazards of consumption.

\section{References}

Aubin, H. (2014). Acute and Long-Term Effects of Cannabis Use: A Review. Current Pharmaceutical Design, 20(25), 4112-4118. https://doi.org/10.2174/13816128113199990620 
Chang, Y. T., Hseu, Z. Y., \& Zehetner, F. (2014). Evaluation of phytoavailability of heavy metals to Chinese cabbage (Brassica chinensis L.) in rural soils. Scientific World Journal, 309396. https://doi.org/10.1155/ 2014/309396

Chojnacka, K., Chojnacki, A. H., Górecka, H., \& Górecki, H. (2005). Bioavailability of heavy metals from polluted soils to plants. The Science of the Total Environment, 337, 175-82. https://doi.org/10.1016/ j.scitotenv.2004.06.009

Groenenberg, J. E., Römkens, P. F. A. M., Van Zomeren, A., Rodrigues, S. M., \& Comans, R. N. J. (2017). Evaluation of the Single Dilute $(0.43 \mathrm{M})$ Nitric Acid Extraction to Determine Geochemically Reactive Elements in Soil. Environmental Science \& Technology, 51(4), 2246-2253. https://doi.org/10.1021/ acs.est.6b05151

Kapustka, L., Biddingers, G., Luxon, M., \& Galbraith, H. (2004). Landscape Ecology and Wildlife Habitat Evaluation: Critical information for ecological risk assessment, landuse management activities and biodiversity enhancement practices (p. 42). ASTM International, West Conshohocken, PA, USA. https://doi.org/10.1520/STP1458-EB

McLaughlin, M., Hamon, R., McLaren, R., Speir, T., \& Rogers, S. (2011). Review: a bioavailability based rationale for controlling metal and metalloid contamination of agricultural land in Australia and New Zealand. Australian Journal of Soil Research, 38(6), 1037-1086. https://doi.org/10.1071/SR99128

McPartland, J., \& McKernan, K. (2017). Contaminants of Concern in Cannabis: Microbes, Heavy Metals and Pesticides. In S. Chandra, H. Lata, \& M. ElSohly (Eds.), Cannabis sativa L.—Botany and Biotechnology (pp. 457-474). Springer, Cham. https://doi.org/10.1007/978-3-319-54564-6_22

Nash, M., Bradley, O., Zhongwei, W., Huifang, X., \& Janice, T. (2014). Simple X-Ray diffraction techniques to identify MG calcite, dolomite, and magnesite in tropical coralline algae and assess peak asymmetry. Journal of Sedimentary Research, 83, 1084-1098. https://doi.org/10.2110/jsr.2013.67

Ogasawara, S., Nakao, A., \& Yanai, J. (2013). Radiocesium interception potential (RIP) of smectite and kaolin reference minerals containing illite (micaceous mineral) as impurity. Soil Science and Plant Nutrition, 59(6), 852-857. https://doi.org/10.1080/00380768.2013.862158

Olowoyo, J. O., Okedeyi, O., Mkolo, N. M., Lion, G., \& Mdakane, S. T. R. (2011). Uptake and translocation of heavy metals by medicinal plants growing around a waste dump site in Pretoria, South Africa. South African Journal Botany, 78, 116-121. https://doi.org/10.1016/j.sajb.2011.05.010

Sarma, H. (2011). Heavy metal contamination of drinking water in Kamrup district, Assam, India. Environmental Monitoring and Assessment, 179, 479-486. https://doi.org/10.1007/s10661-010-1750-7

Schwertmann, J. (1999). Colour identification of iron oxides and hydroxysulfates. Soil Science Society of America, 63, 1463-1471.

Thomas, C., Brian, F., \& ElSohly, M. (2016). The analytical chemistry of Cannabis. Elsevier.

\section{Copyrights}

Copyright for this article is retained by the author(s), with first publication rights granted to the journal.

This is an open-access article distributed under the terms and conditions of the Creative Commons Attribution license (http://creativecommons.org/licenses/by/4.0/). 